\title{
Tueak Serembeak: The Role of Parenting in Early Character Development and Education
}

\author{
Lili Triani $^{1}$ \\ Sofia Hartati ${ }^{2}$ \\ R.Sri Martini Meilani ${ }^{3}$
}

Universitas Negeri Jakarta, Indonesia ${ }^{1,2,3}$

DOI: https://doi.org/10.21009/JPUD.152.05

Accepted: September $15^{\text {th }} 2021$. Approved: October $4^{\text {th }} 2021$. Published: November $30^{\text {th }}, 2021$

\begin{abstract}
The challenge of implementing character education has an impact on the development of children's character. This study aims to describe the form of parenting using tueak serembeak in early character development and education in the Rejang tribe. This qualitative research uses a case study method with two male respondents. Data was collected by documentation, interviews, observations, and field notes and analysed using the Miles and Huberman stages. The theoretical study as the basis of research shows that tueak serembeak can form twelve characters in early childhood, responsibility, courage to take decisions, sharing, caring, survival, tenacity, cooperation, hard work, never give up, keep the spirit, dare to accept challenges, and be patient in dealing with problems. However, the findings in the field show that there are only four characters that appear, being responsible, sharing, caring and patient in dealing with problems. Other characters that appear not based on the teachings of tueak serembeak are independent, creative, and friendly characters. This happens because of the influence of external intervention, education in Air Raman Village, which has developed, advanced technology and open community life. A suggestion for further research, is experimental research based on tueak serembeak teachings that can explain more clearly the influence of this teaching on other aspects of child development.
\end{abstract}

Keywords: Early Character Development, Parenting, Tueak Serembeak

\footnotetext{
${ }^{1}$ Corresponding Author:

Pascasarjana, Pendidikan Anak Usia Dini

Universitas Negeri Jakarta

Email: lilitriani1123@gmail.com
} 


\section{INTRODUCTION}

Character in children is influenced by the culture in which they are raised (Lee, 2013). These characters include moral values, attitudes and behaviour, motivation and skills as a manifestation of human moral values and capacities in facing difficulties (Sriwilujeng, 2017). A variety of character-education programs have been implemented with children and assessed for efficacy. Many character education programs aim to instil children, children the values virtues necessary human flourishing, which is defined as the realization of virtues of thought and character, as well as the fulfilment other physical and mental potentialities throughout one's life (Bavarian et al., 2013).

According to Semke and Sheridan's (2011) study, there is a causal relationship between parental participation in children's learning and academic outcomes. However, little study has been done to see if including parents in their children's character education has an impact on their character results. The lack of study in this area is likely related to the fact that most character education programs are not administered in homes. The findings Paul et al., (2020) indicate that it is helpful in including parents in their children's character education.

Parents and children consciously interacting with conceptions of character in everyday life resulted in improved knowledge of virtue and character. Paul et al., (2020) discovered that the words and concepts gave parents a tool to use when dealing with behavioural challenges. These findings corroborate those of previous parent-involved character education research (e.g. Berkowitz et al., 2021; Castro-schilo et al., 2012; Diana et al., 2021).

The diversity of ethnic groups in Indonesia forms a diverse parenting role, one of which is the Rejang Tribe, which is one of the oldest tribes on the island of Sumatra. The Rejang tribe uses Tueak Serembeak to assist parents in raising children to shape their character. Tueak serembeak is advice, advice, in educating children or grandchildren through the means of the Rejang literary language in the form of prose, poetry, parables, expressions and parables (Ekorusyono et al., 2015). Tueak serambeak is used in interactions that occur in the internal sphere of the family and externally in the community for education and teaching.

Several studies on the role of parenting in the formation of character in early childhood have been carried out, such as the process of parenting in the Bajo family, Bone district, which incorporates cultural values in the process of parenting and education (Musi et al., 2015). The Samin community has binding teachings on character cultivation (Adhe, 2014) and parental involvement in early childhood care in China (Zong et al., 2017). Di In Taiwan, character education applied in the family is also able to improve good relations between parents and children (Mei-ju et al., 2014). The relationship between insight and parenting dimensions was investigated by (Gomez et. al., 2019). Thus, this study aims to explore the character formed from tueak serembeak, examine the form of parenting that 
uses Tueak Serembeak, and the impact of parenting forms Tueak Serembeak in the development and early character education of the Rejang tribal community.

\section{THEORITICAL STUDY}

\subsection{Early Character Development and Education}

Characters in children, their typical way of responding to emotional events, getting new stimuli and impulses is influenced by the genetic system of parents (Zhe \& DeaterDeckard, 2013). As well as sooner or later in the learning process obtained from everyday experience is influenced by genetic factors (Luciano \& Visscher, 2012). There are also six pillars of character education according to Hariyanto (2012) character counts, including the following, (1) Trustworthy, such as being honest, being reliable, being brave and being a good friend. (2) Respect, such as treating other people as they want to be treated by others, being polite and civilized, listening to what others have to say, not insulting others, not threatening, not judging others before knowing them. (3) Responsibility, being a reliable person, running affairs well, being responsible for what is done, thinking before acting. (4) Honesty (Fairness), getting used to queues, telling the truth, playing by the rules, thinking about the impact of our actions, listening to others with an open mind, not blaming others for mistakes, not taking advantage of others, not acting on likes personal, (5) Caring, treating others with kindness, helping others, being sensitive to other people's feelings, not hurting. (6) Citizenship, such as sharing, being responsible for the surrounding environment, participating in the community, caring for the natural environment, following the applicable rules.

Children with character have a natural in responding to situations morally and through real actions and have the intrapersonal, interpersonal, ability to use logic and can feel things. The child's character will be rooted in his personality and is a machine that drives how a person acts, behaves, says and responds to something in the future (Kertajaya, 2010). Characteristics Early childhood (0-8 years) is an individual who is undergoing a very rapid process of growth and development.

Characteristics of early childhood according to McDevitt and Ormrod (2015), children have extraordinary levels of creativity and imagination. Children see life as a place for imagination, drama and discovering something new. Children have a high sense of curiosity. Language and communication skills develop rapidly, have new vocabulary, and understand the rules of communication. Children of this age also have very rapid motor development. They run, jump, tend to be unable to stay still in one place. Socially emotional they are more confident and affectionate in dealing with adults. Have peers to play with by using their imagination. Sometimes they can be aggressive and selfish of their fellow friends.

Every child has different characteristics. The characteristics of children are partly formed from internal and from external. Although the characteristics of children are different, they still have a basis that is used as a reference for early childhood development 
to run normally or not. The basis for this reference is contained in the STPPA (Standard Level of Child Development Achievement) which is included in the Minister of National Education Regulation number 137.

\subsection{The Role of Parenting for Early Character Development and Education}

The parenting process is the concept of classifying parental practices with their children using a behavioural approach in which there is a parental response in the form of warmth and support and there is demands or control of the child's behaviour (Acar et al., 2017). This parenting process is carried out since the child is still in the womb, as revealed by (Maas et al., 2016) that parenting is a process of adjustment to the surrounding conditions that begins during pregnancy and continues to develop throughout the child care period. The role of nurturing during pregnancy can develop a component of cognitive, affective behaviour that is linked to the system of care during pregnancy. Positive parenting is defined as parental behaviour based on the best interests of the child in terms of nurturing, caring for, empowering without violence, providing guidance, and giving recognition to the child's self-development (Freijo et al., 2018). The result of positive parenting is that children can explore their learning environment so that they have a positive learning experience.

In the process, children develop the cognitive abilities needed to obtain information from an experience and be able to apply it (September et al., 2016). According to positive parenting is the ability to mobilize children's social competence and positive parenting comes from the optimistic nature of parents, because individuals who have an optimistic nature will get better. Positive parenting has a good impact on child development. Positive parenting comes from parents who can adjust to the stages of child development. In addition, children get abundant love from parents, there is no element of violence and coercion in this positive parenting, so that the development and character of children can grow well. The parenting role has several types of parenting as written by (DalimonteMerckling \& Williams, 2020) which says that parenting is divided into four types, the authoritative parenting style, the authoritative parenting style, the permissive parenting style and the indifferent parenting style.

The family is the first institution for children. Children will be cared for, formed and raised in a family environment (Daniel et al., 2016). Every family has a different parenting style. Parenting has a fundamental influence on the development of children and can increase the interaction between parents and children. The care provided by the family will have an impact on the survival of the child and will be attached to the child into adulthood. The diversity of parenting ways is a strategy used by parents to shape their children based on the application of parenting used. Parents use a behavioural approach in which there is a response from parents who contains warmth, support and demands in controlling children's behaviour (Acar et al., 2017). This parenting process involves both parents by providing responses, support, and orders to the child so that the child becomes a good person in the future. This parenting process should be carried out since the child 
is still in the womb. The parenting pattern in this study is authoritative with a positive parenting role that makes children have abundant affection, there is no element of coercion from parents, caring for, nurturing, guiding, and providing the best education for children. Children are given the freedom to explore their world but there are still limits given by parents, so that the development of children's character can be optimal.

\subsection{Parenting in Rejang Tribe Culture}

The geographical location of the land of Rejang is in most areas of Bengkulu province and a little in the province of South Sumatra, of the nine districts and one municipality in Bengkulu province, five of which are inhabited by the Rejang tribe. This means that more than half of the Bengkulu province is home to the Rejang tribe, which is spread across the districts of Lebong, Rejang Lebong, Kepahiang, known as Jang Belek Tebo and North Bengkulu district, and Central Bengkulu district, known as Jang Pesisia.

The Rejang people divide their territory into two parts, 1) Jang belek tebo, the Rejang people who inhabit the area behind the hill/mountain, consisting of three regencies, Kepahiang, Rejang Lebong and Lebong. The topography is mostly mountainous areas, highlands with tropical forests and fertile soil, 2) Jang Pesisia, the people who inhabit the coastal area include two districts, namely North Bengkulu and Central Bengkulu. The topography is mostly lowland, swamp, forest, tropical and coastal areas.

The Rejang people in general still highly value their ancestral tueak. They consider and view the knowledge sought in school is not perfect if it has not been combined with "tueak" namely knowledge obtained from ancestors both living and dead. Ancestral tueak is a knowledge that is obtained through mandates, advice, ancestral advice with figurative language in the form of serambeak as a means of delivery.

Tuek literally means advice. The Rejang tribe interprets Tuek depending on the context of the object. In the context of heredity, it means excellence, which is superior in terms of fame, honour, and wealth. In a personal context, tueak means magic, sacred has charisma, authority, luck because of its advantages over other people. Meanwhile, when viewed from the side of education, tueak has the meaning of inheriting values of spirit, tenacity, fortitude, and ingenuity in overcoming life's problems. The Rejang tribe uses the serambeak method as a means of education when formal education is inadequate or even non-existent. Formal education began to be known since the invaders entered the land of Rejang around the 18th century and can only be enjoyed by certain people.

Serambeak is very effective as a means of incorporating the noble values of the Rejang tribe so that they are passed down from generation to generation. Besides the language is smooth, few words, easy to remember, because the form is in the form of lyrical prose, poetry, proverbs, parables, proverbs, and slogans. Tueak Serambeak is classified as an educational facility because there is an element of educative interaction in it. Tueak serambeak is used in interactions that occur in the internal sphere of the family and externally in the community that is intended for educational and teaching purposes. Tueak serambeak can be used in various situations that function at certain important moments 
such as when an incident takes place and there is a need for advice, initiation of maturity, allowing children to go abroad, special family times and certain ceremonies. Utilization of the right time in tueak serambeak affects the child so that it is firmly embedded in him.

It can be concluded that tueak serambeak is more inclined to the educational context, its function is closely related to parenting and educating children in the family sphere through figurative language. Serambeak is an oral literature of the Rejang ethnic group in the form of petitih petatah with very subtle language as an expression of conscience that is used as a vehicle for education, which is spoken in every important activity that contains ideas, ideas, myths of the Rejang community. So, tueak serambeak is advice, advice, in educating children or grandchildren through the means of the Rejang literary language in the form of prose, poetry, parables, expressions and parables. (Ekorusyono et al., 2015)

As for examples of tuek serambeak in life which contain advice from parents to their children, (1) Tueak idup jijai sbong, the meaning is for boys who are born to be real men. A real man must make sure what he does need to be done and ensure that what he does is useful. The beginning of a man is the courage to do something without fear of failure, if you fail at least have tried. (2) uku magiak isai dado, which means to share knowledge that is not learned in school but life science. Experience has taught a person a lot to be a wise person. Wisdom does not appear by itself. It crystallizes from various inputs with conscious effort. (3) lak idup sitak nyabai, meaning that if you want to survive you must be ready in all circumstances. The ability to survive that God has given is a provision for human efforts to get out of the difficulties they face. Difficulty in life trains a person to get used to being difficult and life full of challenges, (4) jano najak kuat maro, the meaning is to invite friends to work, come on, don't refuse the important thing is halal. Working hard by exerting all the effort and sincerity is seen as the most important effort. (5) Cayeak tenokok, aleak tanaen, the meaning is to have an unyielding spirit even though you are weak, to lose in everything but must fight against all circumstances until victory comes. Having a heroic spirit or heroism. (6) gen ba ksapei ne nadep, which means that whatever happens in front of your eyes, all obstacles and obstacles that come in your way, like it or not, must be faced. Face the problems that exist, there is no success without obstacles and no obstacles that cannot be removed.

Through tueak serambeak that is done by parents to their children, it is hoped that they can be practiced in their children's lives. This is done when the child is still at an early age so that the inputs given can crystallize in the child and become a good character when the child grows up. The Rejang people who live in Air Raman village are the Rejang people called Jang Belek Tebo. This is because the topography of Air Raman village, which is surrounded by mountains, has fertile and cool soil. The people in Air Raman village have a livelihood as coffee, green vegetables, and pepper farmers. In the village of Air Raman, the customs of the Rejang tribe are still very strong, such as traditional wedding ceremonies, traditional ceremonies of death and ceremonies for newly born children. Every traditional ceremony carried out will be led by a traditional leader by 
reading the tueak serambeak. Tueak serambeak which contains advice using the subtle Rejang language.

\section{METHOD}

This study uses a qualitative approach to the design of the case study method. It was conducted to describe how the role of "tueak serembeak" parenting in the formation of early childhood character in the Rejang tribal community. This research is in Air Raman Village, Kepahiang Bengkulu for three months.

\subsection{Participant}

The informants in this study were two boys aged 5-6 years with the following characteristics: a family background from the Rejang tribe and using "tueak serembeak" to assist the parenting role performed by parents. Other informants were parents, village heads and PAUD teachers.

\subsection{Instrument}

The instrument in this study is based on everyday life examples obtained from the teachings of "tueak serembeak". There are six examples of these teachings whose meanings are then transformed into indicators of early character development and education (see Table 1).

Table 1. Instrumental Grid of the Role of Parents in Formation of Early Childhood Character in Rejang Tribe Society

\begin{tabular}{ll}
\hline \multicolumn{1}{c}{ Aspect } & Indicator \\
\hline Tueak idup jijay sbong (a boy born must be a real man) & Responsible \\
& Dare to take a decision \\
\hline Uku magiak isi dado (share knowledge that is not & Mutual sharing \\
taught in school, life science) & Care \\
Lak idup sitak nyabai (If you must survive, you must & Survive \\
be ready with all the circumstances) & tenacious/tough \\
Jano najak kuat, maro (If someone invites you to & Work Hard \\
work, let's do it) & Cooperation \\
\hline Cayeak tenokok, aleak tanean (must have an & Never Give up \\
unyielding soul) & Stay Positive \\
Gen ba ksapei ne, nadep (whatever happens in front of & Dare to accept challenges \\
the eyes must be faced) & Be patient with problems \\
\hline
\end{tabular}

\subsection{Procedure}

Before conducting the research, the researcher first carried out several pre-research stages, including preparing a research design. This is done so that there is a match between what will be studied and the formulation of the problem that has been made. Furthermore, choosing a research field so that the chosen research location is in accordance with the circumstances to be studied. In this case, the research location chosen by the researcher is in Air Raman Village, which is a community of the Rejang tribe who uses tueak serembeak to help parents in the parenting process to shape the character in early 
childhood. Then proceed with exploring and assessing the field, researchers look at the situation and conditions in the field, see an overview of demography, customs, cultural contexts, habits, education, religion, and livelihoods, selecting and utilizing informants in accordance with the research concept, preparing equipment during research such as pens, books, cellphones and so on. Then the last one is doing ethics in research by establishing good communication with informants to get information, data, documentation in accordance with the formulation of the research problem.

\subsection{Data Collection}

In this study, the data collection techniques carried out were divided into three, namely, participatory observation, unstructured interviews, and documentation. The Researchers saw first-hand how the children's activities and interactions with their parents were from waking up to go back to sleep. Researchers observed the characters that appeared in children. The results of the observations will be written into field notes, which are coded CL. Next is unstructured interviews, the atmosphere of question and answer with resource persons is carried out informally. The interview process flows like interacting in daily activities. In this case, the interviewees were the village head, teachers, parents, and children. Furthermore, the results of the unstructured interview will be given a $\mathrm{CW}$ code. Documentation in this study contains photos of activities carried out by children, photos of the natural surroundings, photos with teachers and friends. Then the results of the photo will be represented and given a CD code.

\subsection{Data Validity}

Test the validity of the data using four stages, namely credibility, transferability, dependability, and confirmability. Credibility is carrying out scientific research so that the level of confidence in an invention can be achieved, and the data provided by the researcher is in accordance with the reality in the field. Transferability is that before conducting a study, the researcher first conducts initial observations to observe events within the scope of the research. Collect as much data as possible that have the same context in the research indicators. Dependability is the reliability of the research which will be added to other factors that are interrelated at the time of the research. Confirmability is the concept of objectivity in non-quantitative research. Something can be said to be objective if several people have the same view, can be trusted and confirmed the truth. (Moleong, 2010).

\subsection{Data Analysis}

In analysing the data, the author requires several stages of research to be used. The stages of this research refer to the three components of the Miles and Huber-man model, namely condensation data, display data and drawing conclusions/verification ((Miles et al., 2014). 


\section{Data Condensation}

Categorize the data into several categories, namely field notes coded (CL 1 and CL 2), child interviews (CWA1,

CWA2), teacher interviews (CWG), village head interviews

(CWK) and parent interviews (CWO1, CW02)

\section{Conclusion/Verification \\ If the conclusion is supported by valid and consistent evidence}

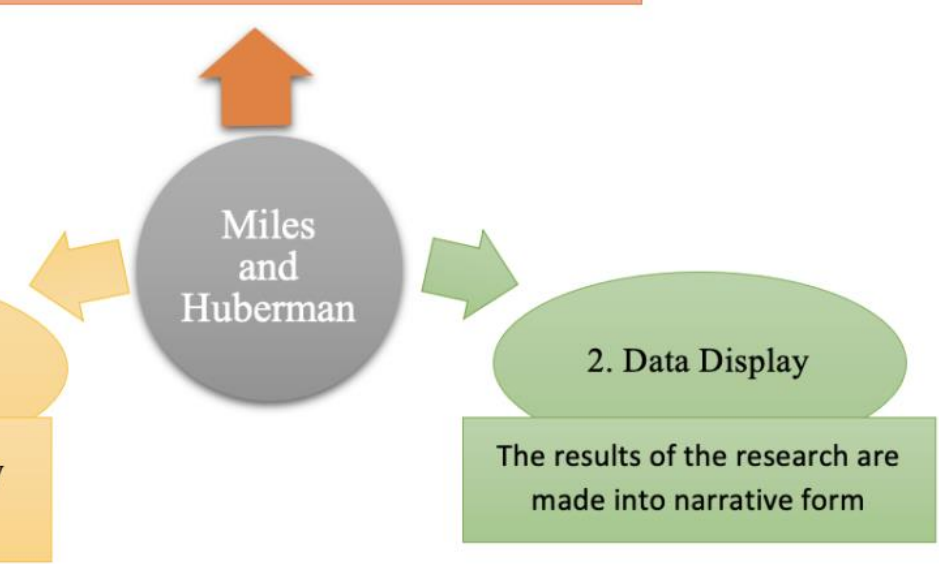

Figure 1 Data analysis of the Miles and Huberman Model

Data condensation is summarizing what is found in the field. Choose what is important, focus on the formulation and research objectives and make a pattern of relationships between the two. The data condensation of this research includes the results of field notes, interviews, documentation, which will then be summarized, coding, formulating, grouping, and presenting the data in writing.

Display data is a collection of structured information that gives the possibility of drawing conclusions and acting. In this research, the researcher uses data display in the form of a narrative that goes into the chart. Finally, the conclusions found at the beginning of the study are only temporary, and the data obtained can change if no strong evidence is found to support the next data stage. If the conclusion is supported by valid and consistent evidence, the conclusion will be valid evidence.

\section{RESULT AND DISCUSSION}

\subsection{Result}

In general, the character of early childhood in the Rejang tribe is the same as the character of other early childhood children. This character is formed from parental upbringing, which is influenced by the surrounding environment. Tueak Serembeak is a means for parents to form character in their children. Tueak serembeak contains advice, advice in educating children or grandchildren through the literary language of Rejang, which can be in the form of prose, poetry, or parables. 
Table 2. Characters of Early Childhood in the Rejang Tribe

\begin{tabular}{lll}
\hline Character Based & Appears & Not Appears \\
Tueak Serembeak & $\sqrt{ }$ & $\sqrt{ }$ \\
\hline Responsible & $\sqrt{ }$ & \\
Dare to take a decision & $\sqrt{ }$ & $\sqrt{ }$ \\
Mutual sharing & & $\sqrt{ }$ \\
Care & & $\sqrt{ }$ \\
Survive & $\sqrt{ }$ \\
tenacious/tough & $\sqrt{ }$ \\
Work hard & & $\sqrt{ }$ \\
Cooperation & & $\sqrt{ }$ \\
Never give up & & \\
Stay positive & & $\sqrt{ }$ \\
Dare to accept challenges & & \\
Patience in dealing with problems & $\sqrt{ }$ &
\end{tabular}

Table 2 shows the results from the meaning of tueak serembeak and then translated into indicators in the form of characters that will be used in the research process. This is to see what characters emerge with parenting roles based on tueak serembeak. There are twelve characters resulting from the meaning of tueak serembeak. However, of the twelve indicators, only four characters appear in children during the parenting process, namely indicators of responsibility, sharing, caring, and being patient in dealing with problems.

\subsection{Discussion}

Tueak Serembeak is expected to be able to form twelve characters in early childhood, namely responsibility, courage to take decisions, sharing, caring, survival, tenacity, cooperation, hard work, never giving up, staying enthusiastic, daring to accept challenges, and being patient in dealing with challenges. Face A problem, however, what happened in the field, there were only four characters that appeared, being responsible, sharing, caring and patient in dealing with problems. Furthermore, there are other characters that appear not based on the teachings of "tueak serembeak", independent, creative and friendship characters. This can happen due to the influence of external intervention, education in Air Raman Village that has developed, advanced technology such as the Internet and the life of the Rejang tribe of Air Raman villagers who have opened.

\subsubsection{Responsibility Character}

Cultivate the character of responsibility through daily activities that are usually carried out by children such as making their own beds, tidying up their own toys, sweeping and mopping floors. This activity is an activity that has been agreed upon by the subject and his parents so that it becomes the task given to the subject. This is in accordance with the opinion (Listyarti, 2012) that responsibility is the attitude or behaviour of a person to carry out his duties and obligations, which he should do to himself and the people and the surrounding environment. Furthermore Gü (2017) reinforces that a responsible person respects himself and others, fulfils his own duties, performs his own duties, does not interfere with others, considers himself responsible for his feelings, thoughts and 
behaviour. By being given tasks by parents, children will get used to being responsible for carrying out the tasks that have been given this will really help children in the future to always be the person who is responsible for completing the tasks given. In addition to implementing the responsibilities carried out by parents, at school should also be given tasks related to responsibilities so that children are accustomed not only at home but also in the school environment, children continue to carry out their responsibilities. As it is done by early childhood in Japan, the teacher divides the children into groups of 5-6 people, given the task of maintaining the cleanliness of the class, preparing lunch, taking care of the class and so on. The schedule on duty will be arranged every week, and group members will be changed regularly (Mulyadi, 2020).

\subsubsection{Sharing Character}

The character of sharing is an important part of children's social development and plays a key role in children's daily social interactions with their peers while in the school and home environment (Asscheman et al., 2020). This sharing character can foster affection and love for fellow friends and family. Sharing characters can be taught by parents through sharing food, sharing toys, stationery and sharing tasks in helping with homework. Through the character of sharing, children will get used to always paying attention to their surroundings. Children will become more sensitive to the environment around them. What children see can be immediately felt by children so that this sharing character appears. The character of sharing should be done repeatedly and continuously so that it becomes more attached to the child.

\subsubsection{Caring Character}

Caring characters can be done by watering plants and feeding pets such as cats, fish, chickens, and ducks. This is reinforced by Listyarti (2012) who says that every attitude and action always want to give help to other people and communities in need. The role of parenting can be done by reading stories that can foster caring characters in children. Children will easily understand the stories given by parents. In addition, to form a caring character, it must be done repeatedly and consistently.

\subsubsection{Patient in Dealing with Problems}

The character is patient in line with the opinion of Hodijah et al., (2018) which says that patience is a form of refraining from all the trials it faces. Children must be taught to be patient about an early age and teachers, or parents can teach children to be patient by doing daily activities carried out by children. Subjects are taught to set always aside the money they have, and if they want to buy something it doesn't have to be right away but by saving first, collecting money, and their patient character can be formed. Children are taught to carry out the culture of queuing in public areas, such as queuing when going to use public toilets or queuing when they want to buy food. That way, children will learn about patience, so that if they are trained from an early age, the character of patients will be formed in children until they grow up. 


\subsubsection{Other Characters That Appear Not Based on The Teachings of "Tueak Serembeak}

\subsubsection{Independent Character}

An important finding that appears outside the teachings of Tueak Serembeak is an independent character. Growing independent character is done by giving tasks to children such as bathing, eating, and wearing their own clothes without any help from parents anymore. This is reinforced by Suardani et al., (2016) who say that independence is an individual's ability to regulate himself and not depend on others. Of course, this is not only done in the home environment. Independent character is also formed in the school environment so that the independent character that has been formed can be attached to the child until later adulthood. This is in line with research (Dea et al., 2020) which says that in addition to being done with habituation to form independent characters, teachers play a role in fostering behaviour in children, motivating children to be willing to do all activities that are in accordance with the child's abilities and carried out without depending on the child on other people. With the independence possessed by the child, it will make the child more prepared to face the future because the child has his own beliefs and is not easy to depend on others.

\subsubsection{Creative Character}

The creative character of the subject uses his imagination to play like playing a toy car but using a television remote or making a fence using coloured pencils. Creative is a way of thinking and doing something to produce new ways or results from something that is already owned. Although giving freedom to children to explore things that are close to the environment around children, parents must still accompany and supervise children while they are playing.

\subsubsection{Friendly Characters}

Children who have many friends will have more courage and mental strength. To train children in friendly terms, this is done by playing in groups, through group play activities children will learn to know and communicate with one another. This can also help children's language development because the more children listen, the more children speak. More children express something, then the child's vocabulary will increase. This activity will also make children familiar with one another so that an atmosphere of mutual protection, affection and love can be created.

\subsubsection{The Character of Tueak Serembeak's Teachings Who Has Not Appeared During Observation}

\subsubsection{Tough / Tenacious Character}

Children who can adapt, face challenges and bounce back after experiencing difficulties or problems. Tough children are children who can get up again after feeling failed, sad, or disappointed. For example, a child being ridiculed by his friend will feel sad and disappointed, but he can convey to his friend whom he does not like being teased. 
The child can then return to playing and be cheerful again. This tough character must be nurtured from an early age for children through habituation and repetition that is exemplified by parents or teachers at school. A strong character must be possessed by children so that children are not easily disappointed when what they expect does not go according to their wishes. Parents should also be able to provide understanding to children so that children do not feel disappointed. A tough character will make children stronger and easier to adapt to the circumstances around them later. Of course, this character must be done repeatedly so that it is embedded in the child.

\subsubsection{Hard Work Character}

Furthermore, the character of hard work for early childhood is behaviour that shows genuine efforts in overcoming various learning and task barriers, as well as completing tasks as well as possible (Listyarti, 2012). This character can be grown by giving assignments to children, through folk tales/fairy tales read by parents. Children see through the habits and examples given by their parents. There are children who are unable to complete the tasks given by their teachers at school, but parents must continue to provide encouragement and support to children so that children want to complete tasks seriously and work hard. Parents can give rewards for the hard work that has been done by their children. Of course, this reward is to foster enthusiasm to complete the task well.

\subsubsection{Cooperation Character}

Cultivating a cooperative character can be done by playing for children. Cooperation is needed to prepare active children for their future in social life. Children's cooperative behaviour will be reflected in behaviours such as communication, interaction, deliberation, sharing ideas, decision making, listening, willing to change and exchanging ideas. Through playing together a cooperative character will be formed in children. Children think of strategies on how to win a game. Many aspects involved here such as cognitive aspects, social-emotional aspects, language aspects of children will be stimulated through playing.

\subsubsection{The Role of Parenting from Tueak Serembeak}

\subsubsection{Develop Children's Character}

The role of parents in shaping the character of early childhood in the Rejang tribe cannot be separated from the educational advice known as tueak serembeak. Tueak serembeak was used by ancient parents in the Rejang tribe to help shape the character of the boys of their time. The role of parents is divided into two, namely the role of the father and the role of the mother. The role of the father in the formation of the child's character is to encourage the child to be more independent and help the child in the process of building his confidence. Children learn moral and social values by observing the actions of fathers. Together with the father, the child can play freely, and the father helps the child explore without fear of bad things happening to the child. The child feels safe and comfortable when playing with the father. While the parenting role performed by the 
mother is since the child is still in the womb, the mother teaches emotional development to the child, introduces the good and the bad to the child, the child gets abundant love from the mother so that character can be formed. The role of parenting is a collaboration between father and mother to help children in shaping their character. The parenting style of parents will shape what kind of character the child will have in the future.

\subsubsection{Using Authoritative Parenting with Positive Parenting Roles}

The parenting process in the Rejang tribe uses authoritative parenting with positive parenting roles, namely caring for children, guiding children, providing clothing, food, proper housing for children, giving love so that children grow and develop well and form good characters. This is in line with Freijo et al., (2018) which says that positive parenting carried out by parents for children is nurturing, caring for, empowering without violence, providing guidance, and giving recognition to children's self-development. The positive role of parents has a big impact on children's growth and development, making children have a positive personality, and children's emotional intelligence will also be formed. Parents do not use punishment to children but rather direct children to be disciplined and responsible for the behaviour they do. How are the attitudes and behaviour of parents in applying the rules, teaching values and norms that exist in society, giving love and showing attitudes and behaviours that become role models for children so that they can be used as examples by children? Children will imitate and do what they see and feel through their parents.

4.2.7.3 Parents Are Able to Create a Safe and Positive Learning Environment for Children's Growth and Development

Through the positive parenting role performed by parents, it is hoped that the child will grow into a person of character and able to live after adulthood. The positive parenting role that uses authoritative parenting forms children to become independent, responsible, caring, creative, patient, friendly and sharing individuals because the parenting style used is in accordance with the circumstances of the parents of the Rejang tribal community which places deliberation as the basis for solving problems faced by children, parents, and communicate well with children. This is in line with the results of research Rosyada and Retnomurti, (2016) which says that the use of positive language by mothers will form a positive personality to children. Therefore, good communication between parents and children is needed. Parents speak well in front of children, don't get angry, don't yell at children in front of other people so that children's character can be formed. Building character in children requires patience and toughness from parents. The child's character will be formed if it is done continuously and repeatedly so that the character can crystallize in the child until later adulthood. Therefore, it is necessary to have good cooperation between fathers and mothers in shaping the character of children without having to ignore the norms of money that have been imposed on social life. 


\section{CONCLUSION}

The role of parents in shaping the character of early childhood in the Rejang community cannot be separated from the tueak serembeak which contains advice in educating children through the Rejang literary language which can be in the form of prose, poetry, or parables. Through tueak serembeak which is still used today, it shows that culture can be collaborated with early childhood education and appropriate parenting so that it can lead to a new understanding of the role of parenting in the formation of children's character using tueak serembeak. The impact of positive parenting roles with authoritative parenting that uses "tueak serembeak" is the formation of character from within the child such as responsibility, independence, caring, friendship, creativity and sharing through habituation and example that has been exemplified by parents and teachers at school. Some of the characters that appear are expected to be embedded in the child and be able to become provisions for the child when he grows up.

This research is the first step in exploring and describing the role of parenting in the formation of children's character by using tueak serembeak to assist parents in shaping the child's character and describe the impact of the parenting role that has been carried out by parents. It is hoped that this research can help future researchers that want to explore further the role of parenting in shaping the character of early childhood using tueak serembeak.

\section{REFERENCES}

Acar, I. H., Uçuş, Ş., \& Yıldız, S. (2017). Parenting and Turkish children's behaviour problems: The moderating role of qualities of parent - child relationship moderating role of qualities of parent - child relationship. 4430(September). https://doi.org/10.1080/03004430.2017.1365362

Adhe, K. R. (2014). Penanaman Karakter Anak Usia 5-6 Tahun Pada Masyarakat Samin.

Asscheman, J. S., He, J., Koot, S., Buil, J. M., Krabbendam, L., \& Lier, P. A. C. Van. (2020). Classroom peer preferences and the development of sharing behavior with friends and others. International Journal of Behavioral Development, 44(5), 412423. https://doi.org/10.1177/0165025420911094

Bavarian, N., Lewis, K. M., Dubois, D. L., Acock, A., Vuchinich, S., Silverthorn, N., Snyder, F. J., Day, J., Ji, P., \& Flay, B. R. (2013). Using social-emotional and character development to improve academic outcomes: A matched-pair, cluster- 
randomized controlled trial in low-income, urban schools. The Journal of School Health, 83(11), 771-779. PubMed. https://doi.org/10.1111/josh.12093

Berkowitz, R., Astor, R. A., Pineda, D., DePedro, K. T., Weiss, E. L., \& Benbenishty, R. (2021). Parental Involvement and Perceptions of School Climate in California. Urban Education, 56(3), 393-423. https://doi.org/10.1177/0042085916685764

Castro-schilo, L., Taylor, Z. E., Ferrer, E., Richard, W., Conger, R. D., Widaman, K. F., Conger, R. D., \& Widaman, K. F. (2012). Parenting: Science and Practice Parents' Optimism, Positive Parenting, and Child Peer Competence in Mexican- Origin Families Parents' Optimism, Positive Parenting, and Child Peer Competence in Mexican-Origin $\quad$ Families. September 2013, 37-41. https://doi.org/10.1080/15295192.2012.709151

Dalimonte-Merckling, D., \& Williams, J. M. (2020). Parenting Styles and Their

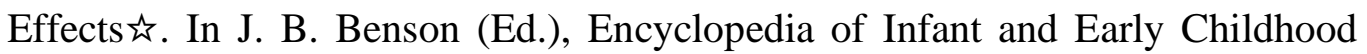
Development (Second Edition) (pp. 470-480). Elsevier. https://doi.org/10.1016/B978-0-12-809324-5.23611-0

Daniel, G. R., Wang, C., \& Berthelsen, D. (2016). Early Childhood Research Quarterly Early school-based parent involvement, children's self-regulated learning and academic achievement: An Australian longitudinal study. Early Childhood Research Quarterly, 36, 168-177. https://doi.org/10.1016/j.ecresq.2015.12.016

Dea, L. F., Anwar, M. S., \& Yusuf, M. (2020). Building Early Childhood Character through KH. Wahid Hasyim Education Model at RA Ma' arif Metro. 6(2), 109120. http://dx.doi.org./0.442/al-athfal.2020.62-02

Diana, R. R., Chirzin, M., Bashori, K., Suud, F. M., \& Khairunnisa, N. Z. (2021). Parental Engagement on Children Character Education: The Influences of Positive Parenting and Agreeableness Mediated by Religiosity. Jurnal Cakrawala Pendidikan, 40(2), 428-444. https://doi.org/10.21831/cp.v40i2.39477

Ekorusyono, Y., Rosyadi, I., \& Tri Bima, P. (2015). Roh kehidupan Suku Rejang. Buku Litera. 
Freijo, E. B. A., López, M. J. R., Freijo, E. B. A., \& López, M. J. R. (2018). Positive parenting in Spain: Introduction to the special issue Positive parenting in Spain: $\begin{array}{llll}\text { Introduction to the } & \text { special }\end{array}$ https://doi.org/10.1080/03004430.2018.1501565

Gomez, Jessie A; Carter, Alice S; Forbes, Danielle; Gray, S. A. o. (2019). Parental Insightfulness and Parenting Behavior: A two-dimensional analysis of parent contributions to child cognitive outcomes. HHS Public Access, 20(3), 255-271. https://doi.org/10.1080/14616734.2018.1446734.Parental

Gü, S. K. (2017). The Education of Developing Responsibility Value *. 5(2), 5-8. https://doi.org/10.11114/jets.v5i2.1361

Hariyanto, S. M. (2012). Konsep dan Model Pendidikan Karakter [Character Education Concepts and Models]. Remaja rosdakarya.

Hodijah, S., Rachmawati, Y., Studi, P., Guru, P., Anak, P., Dini, U., Pedagogik, D., Pendidikan, F. I., \& Indonesia, U. P. (2018). Upaya Guru Dalam Menanamkan Sifat Sabar Di RA Persis I Kota Bandung. EDUKIDS: Jurnal Pertumbuhan, Perkembangan, Dan Pendidikan Anak Usia Dini, 15(229), 95-102.

Kertajaya, H. (2010). Grow With Character, The Model Marketing. PT Gramedia Pustaka Utama.

Lee, G. (2013). Programs: Korean Children's Experiences Re-emphasizing Character Education in Early Childhood Programs Korean Children's Experiences. Childhood Education, $\quad$ October 2014, 37-41. https://doi.org/10.1080/00094056.2013.830907

Listyarti, R. (2012). Pendidikan Karakter dalam Metode Aktif, Inovatif dan Kreatif. Erlangga.

Luciano, M., \& Visscher, P. M. (2012). Multivariate Genetic Analyses of Cognition and Academic Achievement from Two Population Samples of 174, 000. 699-710. https://doi.org/10.1007/s10519-012-9549-7 
Maas, A. J. B. M., Cock, E. S. A. De, Vreeswijk, C. M. J. M., Ad, J. J. M., Bakel, H. J. A. Van, Maas, A. J. B. M., Cock, E. S. A. De, \& Vreeswijk, C. M. J. M. (2016). A longitudinal study on the maternal - fetal relationship and postnatal maternal sensitivity. 6838(April). https://doi.org/10.1080/02646838.2015.1112880

McDevitt, T. M., \& Ormrod, J. E. (2015). Child Development and Education. Pearson Education. https://books.google.co.id/books?id=h7KgBwAAQBAJ

Mei-ju, C., Chen-hsin, Y., \& Pin-chen, H. (2014). The Beauty of Character Education on Preschool Children's Parent-Child Relationship. Procedia - Social and Behavioral Sciences, 143, 527-533. https://doi.org/10.1016/j.sbspro.2014.07.431

Miles, M. B., Huberman, A. M., \& Saldaña, J. (2014). Qualitative data analysis: A methods sourcebook (Third edition). SAGE Publications, Inc.

Moleong, L. J. (2010). Metodologi Penelitian Kualitatif. Remaja Rosdakarya.

Mulyadi, B. (2020). Early Childhood Character Education in Japan. 07063. https://doi.org/10.1051/e3sconf/202020207063

Musi, M. A., Amal, A., \& Hajerah, H. (2015). Pengasuhan Anak Usia Dini Perspektif Nilai Budaya Pada Keluarga Bajo Di Kabupaten Bone [Early Childhood Care Perspective of Cultural Values in Bajo Families in Bone Regency]. 18(1). https://doi.org/10.26858/ijes.v18i1.3601

Paul, S.-A. S., Hart, P., Augustin, L., Clarke, P. J., \& Pike, M. (2020). Parents' perspectives on home-based character education activities. Journal of Family Studies, 1-23. https://doi.org/10.1080/13229400.2020.1806097

Rosyada, A., \& Retnomurti, A. B. (2016). The Use of Positive Language on Children Education to Build Children' s Positive Behaviour. 01(01), 1-8. http://dx.doi.org/10.30998/scope.v1i01.868

Semke, C. A., \& Sheridan, S. M. (2011). Family-School Connections in Rural Educational Settings: A Systematic Review of the Empirical Literature. [superscript 2] Working Papers. Research in Rural Education. 
September, S. J., Rich, E. G., \& Roman, N. V. (2016). The role of parenting styles and socio-economic status in parents' knowledge of child development. Early Child Development and Care, 186(7), 1060-1078. https://doi.org/10.1080/03004430.2015.1076399

Sriwilujeng, D. (2017). Panduan Implementasi Penguatan Pendidikan Karakter [Guidelines for the Implementation of Strengthening Character Education]. Esensi Penerbit Erlangga.

Suardani, L., Pudjawan, K., \& Tirtayani, L. A. (2016). Perbedaan Tingkat Kemandirian Anak Usia 5-6 Tahun Dilihat Dari Status Pekerjaan Ibu Di Kelurahan Banyuning [Differences in the level of independence of children aged 5-6 years seen from the work status of mothers in Banyuning Village]. Journal Pendidikan Anak Usia Dini Undiksha, 4(2), 12. http://dx.doi.org/10.23887/paud.v4i2.7765

Wang, Zhe; Deater-Deckard, K. (2013). Resilience in Gene-Environment Transactions. In Goldstein S., Brooks R. Handbook of Resilience in Children. Springer, Boston, MA. https://doi.org/10.1007/978-1-4614-3661-4_4

Zong, X., Zhang, L., \& Yao, M. (2017). Parental involvement and Chinese elementary students' achievement goals: The moderating role of parenting style. Educational Studies, 5698(October), 1-16. https://doi.org/10.1080/03055698.2017.1373634 